\title{
Effects of Contraception on Cervical Cytology: Data from Mardin City
}

\section{Kontrasepsiyon Yöntemlerinin Servikal Sitoloji Üzerine Etkileri: Mardin Verileri}

\author{
Işık İkbal BARIŞ ${ }^{1}$, Yeliz ARMAN KARAKAYA ${ }^{2}$ \\ 'Department of Pathology, İstanbul University, İstanbul Faculty of Medicine, ISTANBUL, TURKEY \\ 2Department of Pathology, Erzurum Region Education and Research Hospital, ERZURUM, TURKEY
}

\begin{abstract}
Objective: Mardin is an area of low socioeconomic level with low rates of contraceptive method use. Our aim in this study was to evaluate the effects of the contraceptive methods used in the area on epithelial cell abnormalities and vaginal flora changes.
\end{abstract}

Material and Method: Cervical smear samples received at the Pathology Department between 2010 and 2012 of 526 patients who had used a contraceptive method and 112 who had never used one were included in the study. The cases were divided into 3 groups as those using hormonal contraception (107, 20.3\%), those using an intrauterine device $(343,65.2 \%)$ and those using a barrier method $(76,14.4 \%)$. The evaluation was made using the Bethesda 2001 criteria for cervical epithelial abnormalities and specific cervicovaginal infections.

Results: There was no significant difference between the groups for epithelial cell abnormalities while bacterial vaginitis $(12 \%, \mathrm{p}=0.03)$ and Trichomonas vaginalis $(7.6 \%)$ were more common in the IUD users. The Actinomyces rate in RIA users was $1.3 \%$. There was only 1 case of bacterial vaginitis in the barrier group and none of the other patients had a specific infection.

Discussion: We did not find a significant cytopathic effect of using a IUD or hormonal contraception in our study. There was a low rate of epithelial abnormality in the barrier method group. IUD was seen to increase the incidence of bacterial vaginitis, Trichomonas vaginalis and Actinomyces. We did not find a significant effect of hormone use on the vaginal flora.

Key Words: Contraception, Cervix dysplasia

\section{öz}

Amaç: Mardin sosyoekonomik düzeyi düşük ve kontrasepsiyon yöntemi az kullanılan bir bölgedir. Bu çalışmada, bölgede kullanılan kontrasepsiyon yöntemlerinin epitelyal hücre anormallikleri ve vajinal flora değişiklikleri üzerine olan etkilerinin incelenmesi amaçlanmıştır.

Gereç ve Yöntem: Bu çalışmada, 2010-2012 yılları arasında kontrasepsiyon yöntemi kullanan 526 hasta ile hiç bir kontrasepsiyon yöntemi kullanmayan 112 hastanın patoloji bölümüne kabul edilen servikal smear örnekleri değerlendirilmiştir. Olgular, hormonal kontrasepsiyon kullananlar (107, \%20,3), Rahim İçi Araç kullananlar $(343, \%$ 65,2) ve bariyer yöntemi kullanlar $(76, \% 14,4)$ olarak 3 gruba ayrılmıştır. Değerlendirme, servikal epitelyal anormallikler ve spesifik servikovajinal enfeksiyonlar açısından Bethesda 2001 kriterleri kullanılarak yapılmıştır.

Sonuçlar: Değerlendirme sonucunda gruplar arasında epitelyal hücre anormallikleri açısından anlamlı bir farklılık izlenmezken, RIA kullanıcılarında bakteriyel vajinit ( $\% 12, \mathrm{p}=0.03$ ) ve Trikomonas Vajinalis $(\% \quad 7,6)$ görülme sıklığı diğer gruplara göre yüksek bulunmuştur. Aktinomiçes ise RIA kullananlarda \%1.3 olarak saptanmıştır. Bariyer grubunda ise sadece 1 hastada bakteriyel vajinit izlenirken, diğer hastaların hiçbirinde spesifik bir enfeksiyon izlenmemiştir.

Tartışma: Çalışmamızda RIA ve hormonal kontrasepsiyon yöntemi kullanımının servikal hücreler üzerinde anlamlı bir sitopatik etkisi izlenmemiştir. Bariyer yöntemi kullanan grupta epitelyal anormallik düşük oranda görülmüştür. RIA’nın bakterial vajinit, Trikomonas vaginalis ve Aktinomiçes insidansı üzerine arttırıcı etkisi görülmüştür. Hormon kullanımının vajinal flora üzerine anlamlı etkisinin olmadığ

Anahtar Sözcükler: Kontrasepsiyon, Serviks displazi

Correspondence: Işık İkbal BARIŞ

İstanbul Üniversitesi İstanbul Tip Fakültesi, Patoloji Anabilim Dalı,

İSTANBUL, TURKEY

E-mail: isikakgun@hotmail.com Phone: +90 5327028022 


\section{INTRODUCTION}

The potential effects of the contraception methods that are widely used in the community on cervical or endometrial carcinogenesis have been studied by various investigators for many years. Different opinions on this subject are present in the literature.

Our study aimed to investigate the effects of the main contraceptive methods used on epithelial abnormalities and vaginal flora changes in cervical cytology practice with cases chosen from the Mardin province, which is an underdeveloped area in terms of socio-economic features and family planning, and to provide a contribution from the Southeastern Anatolia region to the present literature.

\section{MATERIAL and METHOD}

Pap smears belonging to 526 patients who used a particular method of contraception and were sent to the Pathology department of our hospital during the 2010-2012 period for cervical cytology examination were compared with the smears of 112 control patients who did not use any contraception method. The cases in the study group were divided into three main groups according to the methods of contraception they used: i) Oral contraceptive (OC) method users ii) intrauterine device (IUD) users and iii) Users of barrier methods such as condom and diaphragm. A total of 638 conventional Pap-stained smear samples were comparatively evaluated according to the Bethesda 2001 criteria in terms of squamous or cervical glandular epithelial abnormalities and the most common specific cervicovaginal infections in the region.

As regards the most common cervicitis factors such as Bacterial Vaginitis (BV), Candida species, Trichomonas vaginalis (TV) and Actinomyces: Bacilli invading the squamous cells and forming a "clue cell" appearance as seen cytomorphologically on the slide were used for the diagnosis of BV, while observation of yeast and pseudohyphae structures belonging to Candida types and reactive cellular changes in the squamous cells were used for the diagnosis of Candidiasis. The presence of small, bluish trichomonads was used for TV diagnosis and a purple cotton wool appearance formed by bacilli helped in the diagnosis of Actinomyces. Glandular cells showing characteristics such as nuclear enlargement, rough chromatin distribution, loss of polarity, and pseudo-stratification were evaluated within the context of atypical glandular cells (AGC).

The SPSS 11.5 program was used for statistical analysis. Results with a p value less than 0.05 according to Pearson's chi-square test were accepted as statistically significant. The data obtained were compared with past studies.

\section{RESULTS}

The ages of the patients in the study group varied between 18 and 48 (mean. 25.5) years and the ages in control group between 16 and 51 (mean. 27.5) years. Of the 526 patients in the study group, $65.2 \%(\mathrm{n}=343)$ were using an IUD, $20.3 \%(\mathrm{n}=107)$ a hormonal contraception method and $14.4 \%(\mathrm{n}=76)$ a barrier method (Table I). Numericallly, no significant relationship was found between contraception methods and squamous and glandular epithelial abnormalities, such as ASC-US ( $\mathrm{p}=0.65)$, ASC-H, LSIL, HSIL and AGC (Figure 1).

When we evaluated the cases in terms of specific cervicovaginitis factors in the vaginal flora causing inflammation, a statistically significant relationship was seen between Bacterial Vaginitis (BV) development, one of the most common causes of cervicovaginitis in the region, and the contraception methods used $(\mathrm{p}=0.03)$. BV was observed in 41 (12\%) of a total of 343 patients who used an IUD (Figure 2). BV was observed in 8 patients (7.5\%) of a total of 107 patients using OC and in 10 (8.9\%) of 112 patients who do not use any contraception method ( $\mathrm{n}=$ $10)$. The BV rate (1.3\%) was found to be significantly low $(\mathrm{n}=1)$ in patients using a barrier method (Table I).

No significant difference was found between the groups for Candida infection development, and neither Candida nor TV was observed in patients using barrier method. It is noteworthy that Actinomyces was only seen in the IUD group.

Entities where Pearson's chi-square test could not be applied because of some low values were also evaluated separately according to the use of contraception in Table II. Clearly higher rates of vaginal infection rather than epithelial anomaly are observed in the presence of contraception.

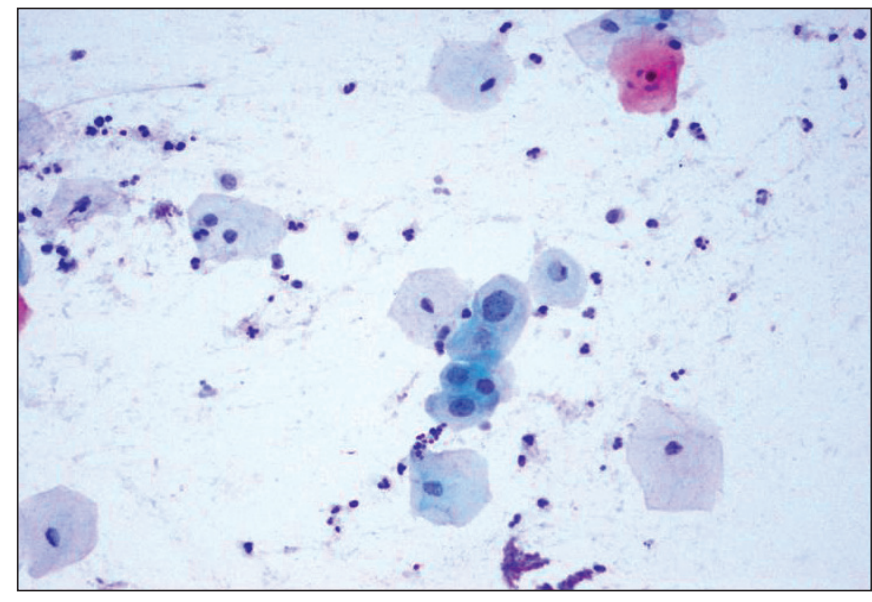

Figure 1: ASC-US cells in patient using RIA (Pap, 40x). 


\begin{tabular}{|c|c|c|c|c|c|c|c|c|c|c|c|c|}
\hline \multicolumn{2}{|c|}{ ङ } & $\Xi$ & $\stackrel{\circ}{\circ}$ & 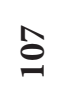 & $\stackrel{\circ}{\circ}$ & fै & $\stackrel{\circ}{\circ}$ & $i$ & $\Xi \circ$ & $\underset{\hat{ర}}{\infty}$ & $\stackrel{\circ}{\circ}$ & \\
\hline \multirow{2}{*}{ 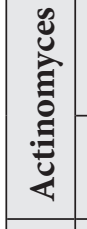 } & g & $\Xi$ & $\stackrel{\circ}{\circ}$ & $\stackrel{\circ}{\circ}$ & $\stackrel{\circ}{\circ}$ & 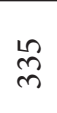 & $\hat{\Omega} \circ \circ$ & $\stackrel{2}{\imath}$ & $\stackrel{a}{\circ}$ & గ్రి & $\stackrel{\circ}{\infty} \circ$ & \\
\hline & $\stackrel{\varnothing}{\mathscr{\nu}}$ & 0 & $\circ \circ$ & 0 & $\circ \circ$ & $\infty$ & $\stackrel{n}{i}{ }^{\circ}$ & 0 & $\circ \alpha^{\circ}$ & $\infty$ & $\stackrel{m}{\rightarrow} \circ$ & \\
\hline \multirow{2}{*}{ 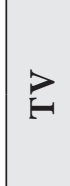 } & ๕ & $\stackrel{\bigcirc}{\exists}$ & $\underset{\infty}{\infty} \circ$ & $\stackrel{+}{\circ}$ & $\underset{\alpha}{\alpha} \circ$ & $\vec{m}$ & $\stackrel{+}{i} \circ$ & 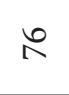 & $\stackrel{0}{\circ}$ & $\hat{\circ}$ & ฝूं ㅇ & \\
\hline & 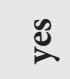 & $N$ & $\stackrel{\infty}{\circ}$ & $m$ & $\stackrel{\infty}{i} \stackrel{\circ}{\circ}$ & $\ddot{i}$ & $\stackrel{\circ}{\wedge} \circ$ & 0 & $\circ \alpha^{\circ}$ & $\vec{m}$ & جे & \\
\hline \multirow{2}{*}{ 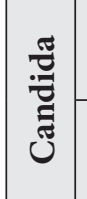 } & 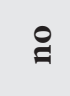 & $\stackrel{2}{0}$ & $\stackrel{\infty}{\alpha} \underset{\circ}{\circ}$ & $\stackrel{\varrho}{\varrho}$ & ֻু & $\overrightarrow{\widetilde{m}}$ & $\underset{j}{0} \circ$ & 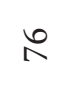 & $\stackrel{9}{\circ}$ & $\stackrel{2}{0}$ & $\stackrel{\infty}{+\infty}$ & \\
\hline & $\stackrel{\mathscr{D}}{0}$ & $\wedge$ & חֶ. $\circ$ & $\theta$ & $\widehat{\hat{m}} \circ$ & $\tilde{N}$ & $\vec{b}^{+}{ }^{\circ}$ & 0 & $\circ$ o & $m$ & î่ $\circ$ & \\
\hline & 巳 & ఠ઼ & $\vec{a} \circ$ & $\alpha$ & 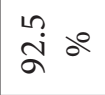 & ర్లి & 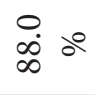 & in & $\stackrel{\alpha}{\infty} \circ^{\circ}$ & 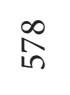 & $\stackrel{\circ}{\circ} \circ$ & \multirow{2}{*}{$\stackrel{\leftrightarrow}{0}$} \\
\hline & 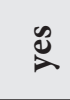 & 우 & $a_{\infty} \circ$ & $\infty$ & $\stackrel{n}{1} \circ$ & $F$ & $\cong \circ$ & - & $\stackrel{m}{\rightarrow} \circ$ & 8 & $\ddot{\sigma} \circ \circ$ & \\
\hline \multirow{2}{*}{ U. } & 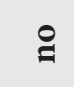 & $\stackrel{一}{\exists}$ & $\underset{\infty}{\infty} \dot{\sigma o ~}^{\circ}$ & $\stackrel{\circ}{\circ}$ & $\stackrel{\circ}{\circ}$ & 앆 & $\vec{a} \circ$ & 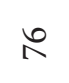 & $\stackrel{0}{\circ}$ & గ్ర & तू & \\
\hline & 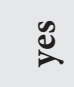 & N & $\stackrel{\infty}{\rightarrow} \stackrel{\circ}{\circ}$ & 0 & $\circ \circ$ & $m$ & $\partial \circ$ & 0 & $\circ \circ$ & in & $\stackrel{\infty}{\circ} \circ$ & \\
\hline \multirow{2}{*}{ 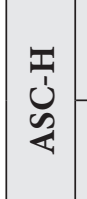 } & ‡ & $\Xi$ & $\vec{\alpha} \circ$ & $\hat{\varrho}$ & 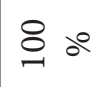 & 윴 & $\vec{\alpha} \circ$ & $\mathfrak{n}$ & 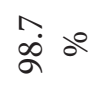 & $\hat{\widehat{\theta}}$ & مू & \\
\hline & 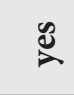 & - & $\hat{\sigma} \circ$ & 0 & $\circ \circ$ & $m$ & $g \circ$ & - & $\stackrel{n}{\rightarrow} \circ$ & in & $\stackrel{\infty}{\circ} \circ$ & \\
\hline \multirow{2}{*}{$\overrightarrow{5}$} & ‡ & $\exists$ & $\stackrel{\circ}{\circ}$ & 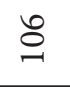 & बें & 윰 & $\bar{a} \circ$ & ㄴ & $\stackrel{\circ}{\circ}$ & 范 & 茨。 & \\
\hline & 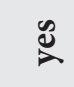 & 0 & $\circ \circ$ & - & $\partial \circ$ & $m$ & $g \circ$ & 0 & $\circ \circ$ & $r$ & $\stackrel{\circ}{\circ} \circ$ & \\
\hline \multirow{2}{*}{$\overline{5}$} & 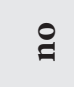 & $\exists$ & $\vec{\alpha} \circ$ & $\stackrel{\circ}{\varrho}$ & $\stackrel{0}{\circ}$ & ैㅏำ & $\widehat{\alpha} \circ$ & 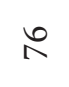 & $\stackrel{\circ}{\circ}$ & ర్రి & $\hat{\alpha} \circ$ & \\
\hline & $\mathscr{Z}$ & - & $\partial \circ$ & 0 & $\circ \circ$ & $\tau$ & $\stackrel{n}{\circ} \circ$ & 0 & $\circ \circ$ & $\sim$ & mo & \\
\hline \multirow{2}{*}{ 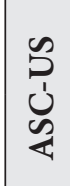 } & ‡ & 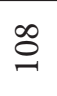 & 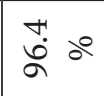 & $\stackrel{\rho}{\varrho}$ & గুం & $\stackrel{\infty}{\sim}$ & 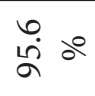 & $\stackrel{n}{N}$ & $\stackrel{\infty}{\infty} \circ$ & $\vec{\sigma}$ & ֶু ஃ & \multirow{2}{*}{$\stackrel{n}{0}$} \\
\hline & 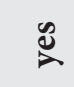 & $H$ & $\stackrel{\leftrightarrow}{\dot{r}} \circ$ & $H$ & $\ddot{\dot{m}} \circ$ & 으 & $\stackrel{+}{+}{ }^{\circ}$ & - & $\stackrel{m}{\rightarrow} \circ$ & $\overleftrightarrow{\sim}$ & $\stackrel{\infty}{\oplus \circ} \circ$ & \\
\hline \multirow{2}{*}{\multicolumn{2}{|c|}{ 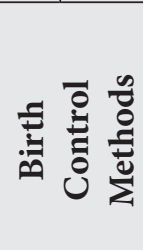 }} & $\Rightarrow$ & वे & $\Rightarrow$ & $\therefore$ & $\Rightarrow$ & $\partial^{\circ}$ & $\Rightarrow$ & o & $\Rightarrow$ & $\partial^{\circ}$ & \\
\hline & & \multicolumn{2}{|c|}{$\vec{\circ}$} & \multicolumn{2}{|c|}{ 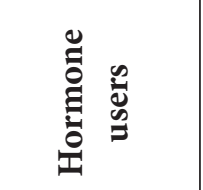 } & \multicolumn{2}{|c|}{ 死营 } & \multicolumn{2}{|c|}{ 氙 } & \multicolumn{2}{|c|}{ } & 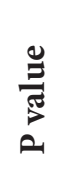 \\
\hline
\end{tabular}


Table II: The incidence of some factors when contraception is and is not used

\begin{tabular}{|c|r|r|r|r|r|r|}
\hline \multicolumn{7}{|c|}{ Contraception Use } \\
\hline LSIL & \multicolumn{2}{|c|}{ yes } & \multicolumn{2}{c|}{ no } & \multicolumn{2}{c|}{ total } \\
\hline HSIL & 1 & $50 \%$ & 1 & $50 \%$ & 2 & $100 \%$ \\
\hline ASC-H & 4 & $100 \%$ & 0 & $0 \%$ & 4 & $100 \%$ \\
\hline AGC & 4 & $80 \%$ & 1 & $20 \%$ & 5 & $100 \%$ \\
\hline Candida & 3 & $60 \%$ & 2 & $40 \%$ & 5 & $100 \%$ \\
\hline Actinomyces & 26 & $78.7 \%$ & 7 & $21.3 \%$ & 33 & $100 \%$ \\
\hline
\end{tabular}

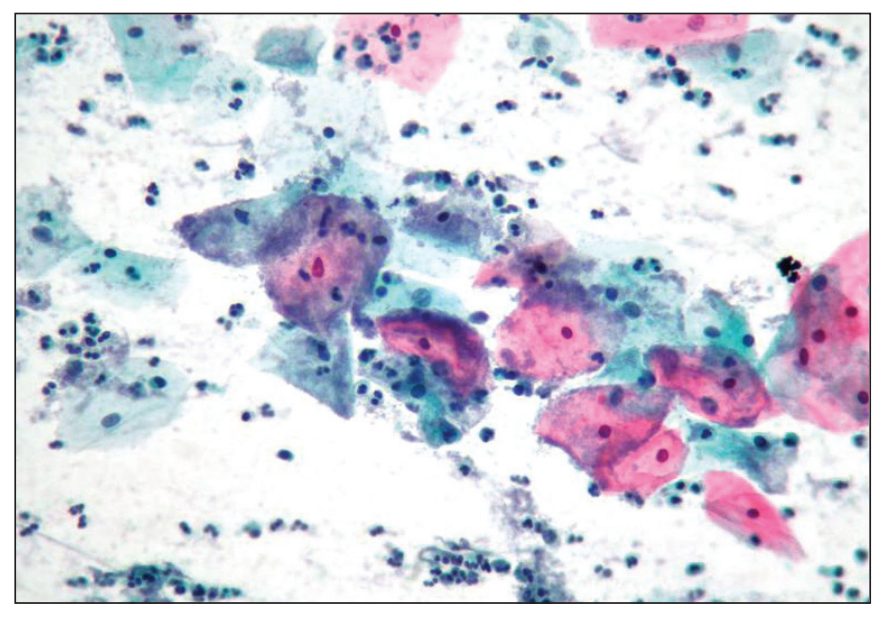

Figure 2: Bacterial vaginitis in patient using IUD (Pap, 40x).

The results obtained from the subsequent examination of our patients where epithelial abnormalities were diagnosed through histopathology techniques, using methods such as cervical biopsy, loop electrosurgical excision procedure (LEEP), and conization, were compared with the smear diagnoses. ASC-US patients were clinically followed up and there was no histopathological evaluation. 13 of 16 patients diagnosed with LSIL, HSIL, ASC-H and AGC underwent histopathological evaluation and the diagnostic consistency rate was $84.6 \%$.

\section{DISCUSSION}

The Southeastern Anatolia Region of Turkey is an area of rapid population growth and slow uptake of family planning. Families often anticipate having a large number of children and are biased against using birth control methods. However, IUD's, oral contraceptives (OC) and barrier methods such as condoms and diaphragms are among the modern contraceptive methods used in order of frequency.

Methods of contraception have always been approached with suspicion over time as they are believed to facilitate cervical and endometrial carcinogenesis, and many studies have especially investigated the neoplastic effects of OC and IUD use. The general conclusion of studies are that shortterm hormone use is not related to cervical neoplasia but use for over 5 years and especially in patients with highrisk Human Papilloma Virus (HPV) infection may cause progression of present dysplasia to carcinoma in situ (14). Moreno et al revealed no increase in cervical neoplasia development risk in patients using OC for less than 5 years. However, the use of OC for more than 5 years was seen to increase risk in HPV (+) women (1). Duggan et al reported OC use not to have any effect on the incidence and persistence of HPV infection (2). These and similar studies have shown hormonal contraception to trigger neoplasia only in women with persistent high-risk HPV infection (3). Steroid hormones are known to increase the expressions of the E6 and E7 proteins that HPV uses to bind to the p53 tumor suppressor gene and inactivate it and therefore cause apoptotic defects and carcinogenesis (4). Melamed et al found a significantly increased carcinoma in situ and dysplasia incidence in women using OC compared to those using a diaphragm or IUD (5).

Castellsague et al found a strong and definite inverse relationship between use of IUD and cervical cancer risk (6). In addition, IUD's have been shown to decrease the risk of endometrial cancer in several studies (7-9). The possible reason is the IUD causing a continuous inflammatory response in the genital tract resulting in the modification of the immune status of the local mucosa (10).

The data from our study are support this notion. No significant risk increase was found with the IUD use in terms of squamous or glandular lesions. The finding that barrier methods prevented transmission of HPV and significantly reduced the risk of cervical lesions is an expected result (11). AGC cases followed up that used contraception all used an IUD, indicating an irritant effect of the IUD especially on glandular cells. 
The only significant effect of contraception methods on cervical cytology appears to be on cervical infections in our study. No statistically significant difference was observed between our contraception groups in terms of BV infection $(\mathrm{p}=0.03)$. The superiority of IUD $(+)$ cases in terms of TV and also numerically is clear. Previous studies found a relationship between the use of IUD and BV and TV infection development (12-14). IUD use can therefore be said to strongly pave the way for BV and TV development. It has not been possible to see the same relationship between Candida and IUD. OCS use depending on its progesterone effect was found to thicken cervical mucus and inhibiting bacteria penetration and thus to prevent colonization of bacteria by reducing the period of menstruation (15).

The values we obtained in this study coincide with the data available in the literature. We hope this information that can be shared with patients will somewhat decrease any contraception-related unnecessary anxiety of the people in the region who are already extremely biased and reluctant regarding family planning.

\section{REFERENCES}

1. Moreno V, Bosch FX, Muñoz N, Meijer CJ, Shah KV, Walboomers JM, Herrero R, Franceschi S: Effect of oral contraception on risk of cervical cancer in women with human papillomavirus infection: International Agency for Research of Cancer multicentric casecontrol study. Lancet 2002, 359:1085-1092

2. Duggan MA, McGregor SE, Stuart GC, Morris S, Chang-Poon $V$, Schepansky A, Honore L: The natural history of CIN 1 lesions. Eur J Gynecol Oncol 1998, 19:338-344

3. Moscicki AB, Hills N, Shiboski S, Powell K, Jay N, Hanson E, Miller S, Clayton L, Farhat S, Broering J, Darragh T, Palefsky J: Risks for incident human papillomavirus and LGSIL devolopment in young females. JAMA 2001, 285:2995- 3002

4. Moodley M, Moodley J, Chetty R, Herrington S: The role of steroid contraceptive hormones in the pathogenesis of invasive cervical cancer: A review. Int Jo Gynecol Cancer, 2003,12:103-110
5. Melamed MR, Flehinger BJ: Early incidence rates of precancerous cervical lesions in women using contraceptives. Gynecol Oncol 1973, 1:290-298

6. Castellsagué X, Díaz M, Vaccarella S, de Sanjosé S, Muñoz $N$, Herrero R, Franceschi S, Meijer CJ, Bosch FX: Intrauterine device use, cervical infection with human papillomavirus and risk of cervical cancer: A pooled analysis of 26 epidemiological studies. Lancet Oncol 2011, 12:1023-1031

7. Beining RM, Dennis LK, Smith EM, Dokras A: Meta-analysis of intrauterine device use and risk of endometrial cancer. Ann Epidemol 2008, 18:492-499

8. Castellsague $X$, Thompson WD, Dubrow $R$ : Intrauterine contraception and the risk of endometrial cancer. Int J Cancer 1993, 54:911-916

9. Curtis KM, Marchbanks PA, Peterson HB: Neoplasia with use of intrauterine devices. Contraception 2007, 75:60-69

10. Solomon D, Nayar R (Eds): The Bethesda System for Reporting Cervical Cytology: Definitions, Criteria and Explanatory Notes, 2nd ed. New York, Springer, 2004

11. Tamer GS, Ozcan SK, Yucesoy G, Gacar G: Doğum Kontrol Y öntemleri ile Trichomonasis Arasındaki İlişki. Türkiye Parazitoloji Dergisi 2009, 33:266-269

12. Roy S: Non-barrier contraceptives and vaginitis and vaginosis. Am J Obstet Gynecol 1991, 165:1240-1244

13. Ceruti M, Canestrelli M, Condemi V, Piantelli G, De Paolis P, Amone F, Tovagliari D: Methods of contraception and rates of genital infections. Clin Epid Obstet Gynecol 1994, 21: 119-123

14. Churakov AA, Kulichenko AN, Suvorov AP, Glybochko PV, Kutyrev VV: Comparative assessment of the diagnostic value of the laboratory diagnostic methods for trichomoniasis. Med Parazitol 2005, 3:22-25

15. Wølner-Hanssen $P$, Svensson L, Mårdh PA, Weström L: Laparoscopic findings and contraceptive use in women signs and symptoms suggestive of acute salpingitis. Obstet Gynecol 1985, 66:233-238 